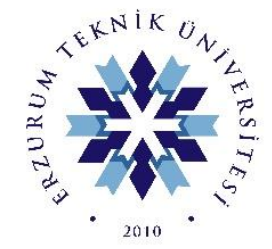

\title{
KADINLARIN YOKSULLUKLA MÜCADELESİNDE SOSYAL YARDIMLARIN ROLÜ: ERZURUM'DA BİR UYGULAMA
}

THE ROLE OF SOCIAL ASSISTANCES IN WOMEN'S STRUGGLE AGAINST POVERTY: A CASE STUDY ON ERZURUM

\section{EMINE DEMET EKINCİ HAMAMCI}

Dr. Öğr. Üyesi, Erzurum Teknik Üniversitesi, İ̈BF, İktisat Bölümü emine.hamamci@erzurum.edu.tr

(iD) https://orcid.org/0000-0003-2808-2186 KÜBRA ANIK

Yüksek Lisans Mezunu, Erzurum Teknik Üniversitesi, Sosyal Bilimler Enstitüsü kubraanik1@gmail.com

(iD) https://orcid.org/0000-0002-3544-9807

\author{
ETÜ Sosyal Bilimler Enstitüsü Dergisi |ETU Journal of Social Sciences Institute \\ S.10, Nisan | April 2020, Erzurum \\ ISSN: 2149-939X

$\begin{aligned} \text { Makale Türü | Article Types } & : \text { Araştırma Makalesi | Research Article } \\ \text { Geliş Tarihi | Received Date } & : 27.03 .2020 \\ \text { Kabul Tarihi | Accepted Date } & : 15.04 .2020 \\ \text { Sayfa | Pages } & : 105-131 \\ \text { dol } & : \text { http://dx.doi.org/10.29157/etusbe.134 }\end{aligned}$

www.etusbe.com

https://dergipark.org.tr/etusbed

This article was checked by

$\boldsymbol{v}$ iThenticate" 



\title{
KADINLARIN YOKSULLUKLA MÜCADELESİNDE SOSYAL YARDIMLARIN ROLÜ: ERZURUM'DA BİR UYGULAMA*
}

\author{
Emine Demet EKINCİ HAMAMCI, Kübra ANIK \\ ETÜSosyal Bilimler Enstitüsü Dergisi (ETÜSBED), S.10, Nisan 2020, Sayfa: 105-131
}

\section{ÖZ}

Birçok toplumda kadınlar istihdam, çalışma koşulları, eğitim imkânları, sosyal yaşama katılım vb. hususlarda erkeklere nazaran daha kötü koşullara sahiptir. Bu durum ise kadınların yoksulluktan daha fazla etkilenmesine ve yoksulluğa karşı daha büyük bir mücadele vermesine yol açmaktadır. Bu mücadelede kadınlara birçok sosyal yardımlaşma kurumu da yardımcı olmaya çalışmaktadır. Ancak "Sosyal yardımlardan kadınlar haberdar mı?" ve "Verilen destekler kadınların sorunlarını çözüme kavuşturabilmekte mi?" sorularını cevaplandırmak önem arz etmektedir. Bu doğrultuda çalışmada farklı kurumlar tarafından verilen sosyal yardımların yoksulluk ile mücadeledeki rolünü ve kadınların bu kurumlara bakış açısını tespit etmek amaçlanmıştır. Çalışmada Erzurum ilinde ikamet eden görece yoksul (ilk \%10'luk dilim) 200 kadın ile bir anket çalışması yürütülmüştür. Araştırma sonuçlarına göre kadınlar hibe şeklinde yardım almaktan hoşlanmamakta ve sosyal yardım kuruluşlarının yardımlarından haberdar olmada sıkıntı yaşamaktadır. Ayrıca parasal destekler sadece günlük ihtiyaçları karşılayabilmektedir. Bunun yerine katılımcılar mesleki yeterlilik kazanabilecekleri imkânlar yakalayarak istihdama katılmak istemektedir.

Anahtar Kelimeler: Kadın Yoksulluğu, Yoksullukla Mücadele Stratejileri, Sosyal Yardımlar, Erzurum

\section{THE ROLE OF SOCIAL ASSISTANCES IN WOMEN'S STRUGGLE AGAINST POVERTY: A CASE STUDY ON ERZURUM}

\begin{abstract}
In many societies, women have worse conditions in matters as employment, educational opportunities, participation in social life, etc. than men. This problem causes women to be more affected by poverty and to struggle against it. Many social assistance organizations also try to help women in the struggle against poverty. But at this point, it is important to answer some questions as "Are women aware of social assistances?" and "Could these supports solve women's problems?". The aim of this study is to determine the role of social assistances aid given by different institutions in the struggle against poverty and women's perspective on these institutions. In the study, a questionnaire has been conducted with 200 relatively poor women (first 10\%) residing in Erzurum. According to the results, women do not like to receive benefits in the form of grants and have difficulties in being aware of the social assistances. In addition, monetary supports could only meet daily needs. Instead, the women desire to participate in employment by capturing some opportunities to enhance their professional competence.
\end{abstract}

Keywords: Women poverty, Struggle against poverty, Social assistances, Erzurum

* Bu çalışma, "Kadınların Yoksullukla Mücadelesi: Sosyal Yardımlaşma Kurumlarının Rolü" isimli yüksek lisans tezinden türetilmiştir. 


\section{Giriş}

Yoksulluk kısaca; günlük temel ihtiyaçların tamamını veya büyük bir kısmını karşılayacak yeterli gelire sahip olamama durumudur. Fiziksel, psikolojik ve sosyal kısıtlılık hali olan yoksulluk; bireylerin karınlarını doyuramamaları, barınacak yer bulamamaları, eğitim ve sağlık ihtiyaçlarını karşılayamamaları, temiz suya ulaşamamaları vb. olarak tanımlanabilmektedir. Yoksulluğun nedenleri ülkeden ülkeye farklılık göstermektedir. Hatta bir ülke içerisinde ikamet edilen bölgeye, yaşa, dini inanca, ırka, dünya görüşüne, eğitime, gelir düzeyine göre de farklılaşmaktadır. Bundan dolayı yoksulluğun nedenleri üzerinde ortak fikir birliği bulunmamaktadır. Ancak ülkeler yoksulluğu yok etmek ya da en azından minimum düzeye indirmek amacıyla gerek ulusal gerekse uluslararası bazda mücadele etmekte ve yoksullukla mücadele stratejileri geliştirmektedir.

Yoksullukla mücadele stratejileri; hibe şeklindeki yardımlardan, kişinin girişimcilik ruhunu geliştirerek daha kalıcı çözüm getirmeye kadar geniş bir yelpazeyi içermektedir. $\mathrm{Bu}$ nedenle belli kalıplar içerisinde sınıflandırılamamaktadır. Ancak gerçekleştirilen etkinlikler sorunun sürekli gündemde tutulmasına ve farklı bakış açılarına sahip stratejilerin geliştirilmesine olanak sağlamaktadır.

Yoksulluğun var olduğu her yerde kadınlar başta yer almakta, maddi ve manevi sıkıntılara maruz kalmaktadır. Neredeyse tüm toplumlarda cinsiyet ayrımcılığı ile karşılaşan kadınlar istihdam, çalışma koşulları, eğitim imkânları, sosyal yaşama katılım vb. birçok hususta erkeklere nazaran daha kötü koşullara sahiptir. Bu durum ise kadınların yoksulluktan daha fazla etkilenmesine yol açmaktadır. Ancak kadınlar başta çocukları olmak üzere ailesinin yüzleştiği yoksulluğu gidermek için yoğun çaba harcamaktadır. Yapılan araştırmalar kadınların yoksullukla mücadelede erkeklere göre daha büyük savaş verdiklerini göstermektedir. Bu sebeple kadınların yaşadığı yoksulluğu ve söz konusu yoksulluğa karşı verdikleri mücadeleyi anlamak önem teşkil etmektedir. Böylece yapılacak doğru tespitler ile ileriye dönük doğru çözüm yollarını bulabilmek mümkün olabilecektir.

Çalışmada Erzurum ilinde ikamet eden yoksul kadınların yoksulluğa karşı verdikleri mücadele ve bu mücadelede sosyal yardımların rolünü tespit etmek amaçlanmaktadır. Bu doğrultuda Erzurum il merkezine bağlı üç ilçe belediyesinde (Yakutiye, Palandöken, Aziziye) ikamet eden ve görece olarak daha düşük gelir grubunda (ilk \%10'luk dilimde) yer alan 200 kadın ile bir anket araştırması yürütülmüştür.

Çalışmanın devamı iki bölümden oluşmaktadır. Birinci bölümde yoksullukla mücadele politika ve stratejileri ele alınarak Türkiye' de yoksullukla mücadele eden kurum ve kuruluşlar ile ilgili kısa bilgiler verilmektedir. Çalışmanın ikinci kısmında 
ise Erzurum'da yoksul kadınlar ile yapılan anket araştırmasının sonuçları aktarılmaktadır.

\section{Yoksullukla Mücadele ve Sosyal Yardımların Mücadeledeki Yeri}

Tarihin her döneminde toplumlar çeşitli nedenler ile ortaya çıkan dar ya da geniş boyutta yoksulluk problemi ile karşı karşıya kalmışlar ve bu problemin çözümü için mücadele etmişlerdir. Ancak yoksulluğun neden ve sonuçlarına ilişkin ilk sistematik çalışmalar 17. yy.de İngiltere'de yaşanan ekonomik ve sosyal dönüşümler sonucu ortaya çıkmıştır (Akçiçek, 2016). Söz konusu dönüşümleri tetikleyen en önemli unsurlardan biri coğrafik keşiflerdir.

Coğrafik keşifler özellikle Batı Avrupa ülkelerinin daha geniş bir coğrafyaya hükmetmesine ve bu coğrafyaların servetinde söz hakkına sahip olmalarına imkân tanımıştır. Bu dönemde hüküm süren Merkantilizm ise sürecin ekonomik dayanağını oluşturmuştur.

Merkantilizm 15. yy. ortasından 18. yy. kadar Batı Avrupa'da iktisadi yapıy şekillendiren sistemdir. "Merkantilizm'e göre değerli madenlere sahip olmak bir ülkenin zenginliğinin kaynağıdır" (Ersoy, 2012: 135-136). Söz konusu değerli madenlere sahip olmanın yolu ise ticarettir. Merkantilistler, bir başka topluluğun yoksulluğuna neden olsa da sömürü ile ülkelerin zenginliğini arttırmayı doğal bir yöntem olarak kabul etmişlerdir.

17. yy.de mülkiyet hakları tartışması ile siyasal bir kuram olarak gelişmeye başlayan liberalizm, merkantilizmin aksine yoksulları dışlamayan bir yaklaşımdır. Dönemin liberalleri bir yandan özel mülkiyet haklarını savunurken öte yandan bu hakkın, yoksul yardımlarını önlememesi gerektiğini ve kişisel refah gibi sosyal refahın da önemli olduğunu savunmuşlardır (Şenses, 2014: 32). Liberal akımın öncüleri olan bu aydınlar Fizyokratlar olarak adlandırılmıştır. Fransa'da yaygınlaşan yoksulluk ve sefaleti önlemeye yönelik bazı çözümler üretmeye çalışan Fizyokratlar için yoksulluk ile mücadelede tek kaynak toprağın insana verdikleri, yani tarım sektörüdür (Ersoy, 2012; Özgüler, 2014).

18. ve 19. yy.de sanayileşmeye dayalı kapitalizm yaygınlaşınca bilim adamları bölüşüm ve yoksulluk problemi ile daha çok ilgilenmişlerdir. "Ekonomi biliminin kurucusu sayılan Adam Smith ülkeler zenginleşirken yoksulluğun artmasını ciddi bir çelişki olarak gündeme getirmiştir. Smith'e göre fertlerinin önemli bir kısmı yoksul olan ülkeler, refah içinde olamazlar ve bu sebeple çalışan yoksullar için daha yüksek ücretler ödenmelidir. Diğer önemli bir iktisatçı Marshall ise yoksulluğun sebebini istihdam ile ilişkilendirmiş ve başkalarının lüks yaşamaları için bazılarının çalışıp çabalamalarının doğanın bir emri olmadığını savunmuştur" (Şenses, 2014: 33-34). 20. yy. sonlarına gelindiğinde ise yaşanan ekonomik krizler sonucu yoksulluk daha yaygın bir hale gelmiştir (Burkett, 1990). Özellikle Soğuk Savaşı'n 
sona ermesi ve küreselleşmenin tüm dünyayı kuşatması, yoksulluğu tüm ülkelerin başlıca problemlerinden biri yapmıştır.

Yoksullukla mücadele stratejileri/politikaları ülkelerin uyguladığı ekonomik sistemin bir sonucudur ve sistemin genel bakış açısını yansıtmaktadır. Bu doğrultuda ülkelerin uyguladığı stratejileri liberal yaklaşım ve sosyal devlet anlayışı şeklinde iki alt başlıkta ele almak mümkündür.

Liberallere göre yoksulluk probleminin kaynağı genellikle devlettir ve yoksulluğun çözümünde devletin etkili olması mümkün değildir (Karagül, 2011). Devlet yalnızca liberal bir ortam oluşturmalıdır. Müdahaleler ve nakit yardımları piyasanın işleyişini bozacaktır.

Liberaller devletin düşük gelirli bireylere yardım etmesinin onları daha erken evliliğe yönlendireceğini, bu nedenle nüfus artışına sebep olacağını belirtmektedir. Ayrıca yüksek gelir elde edenlerin tasarrufları azalacak ve ekonomik büyüme hızı yavaşlayacaktır. Liberaller ekonomik büyümeyi, yoksulluk ile mücadelede en etkin yöntem olarak değerlendirmiş ve ekonomik büyüme gerçekleştiğinde elde edilecek faydaların yoksul bireylere az miktarda da olsa ulaşabileceğini savunmuştur (Kaya, 2009: 89).

Sosyal refah devlet düşüncesi, liberal bakış açısının aksine, yoksulluğun giderilmesinde devletin etkin rol üstlenmesinin gerektiğini savunmaktadır. Devletin örgütlenmesinin sermaye sahiplerinin çıkarlarını korumaktan ziyade, sayıca daha fazla olan düşük gelirli bireylerin çıkarlarını korumak şeklinde olmalıdır. Bu yaklaşıma göre esas amacı kârını arttırmak ve sermaye birikimini sağlamak olan özel sektörü destekleyici ve önünü açıcı politikalarla sosyal içerikli politikaları aynı anda yürütebilmek mümkün değildir (Karagül, 2011: 114). Devlet, yoksulluk problemini çözmek için maliye politikalarını (vergi ve harcama politikaları vb.) etkin olarak kullanmalıdır. Yoksullukla mücadelede devlete önemli rollerin düşeceği ve gelirin yeniden dağıtımı ile yoksulluk probleminin çözüleceği savunulmaktadır.

Yukarıda kısaca ifade edilen bu birbirine tamamen zıt düşünce sistemleri temel alınarak yoksulluğa yönelik dolaylı ve doğrudan şeklinde iki yaklaşım ortaya çıkmıştır.

Dolaylı yaklaşım, büyümenin hızlandırılmasını ve gerçekleşen büyüme ile yoksul bireylerin gelirlerinde ve yaşam standartlarında iyileşmeyi sağlamayı amaçlamaktadır. Büyümenin yoksul bireylerin yaşam standartlarını yükselteceği ve gelir düzeylerini arttıracağı görüşü ortaya çımaktadır. Büyüme hem yoksullukla yakın ilişkisi olan eğitim, sağlık gibi temel hizmetleri sunma kapasitesini ve istihdam olanaklarını arttırırken hem de gelir dağılımını etkileyecektir (Şenses, 2014: 221-222). Ancak ülkelerin büyüme hizları kadar bu büyümenin dezavantajlı kesimlere (kadınlar, çocuklar vb.) yayılımı da önemlidir. Büyümenin olduğu 
yörelerde gelir dağılımı adil bir şekilde gerçekleşmezse yoksulluğun azaltılması yönünde meydana gelen pozitif gelişmelerin faydaları azalacaktır (Şenses, 2014: 223).

Ekonomik büyüme yoksulluğu azaltmada önemli olmakla birlikte, bazen yeterli gelmemekte ve değişik toplum kesimlerini farklı derecelerde etkileyebilmektedir. Bu noktada doğrudan yaklaşım bireylerin ihtiyaçlarının karşılanıp karşılanmadığını ele alarak kıyaslama yapmaktadır. Doğrudan yaklaşım, kamu temel araçlarını (eğitim, sağlık politikaları, vergi vb.) kullanarak gelirin ikincil dağılımına etkin bir şekilde müdahil olmaktadır (Arpacıŏglu ve Yıldırım, 2011). Bu yaklaşıma göre yoksul bireyler diğer bireyler ile eşit bir şekilde kamu hizmetlerine ve kaynaklara ulaşabilirse yoksulluk önemli ölçüde azaltılabilir.

Yoksullukla mücadelede doğrudan mücadelenin etkin olması için;

- Yoksul kitlenin doğru bir şekilde belirlenmesi,

- Yoksullukla mücadelenin kamuoyu tarafından öncelikli bir hedef olarak benimsenmesi ve uygulanacak politikaların halk tarafından desteklenmesi,

- Her kademede hizlı karar alabilecek bürokratların olması ve uygulamanın saydam işlemesi gerekmektedir (Arpacıŏ̆lu ve Yıldırım, 2011: 72).

Yoksullukla mücadelede her ülke kendisine ait bir sistem oluşturarak farklı yapılanmalara gitmiştir. Bazı ülkeler yoksullukla mücadeleyi devlet politikası olarak benimseyip merkezi ve yerel teşkilatını görevlendirirken bazı ülkeler ya Sivil Toplum Kuruluşlarına süreci devretmiş ya da uluslararası çapta kurumlardan (Dünya Bankası, Birleşmiş Milletler, Uluslararası Para Fonu vb.) destek almıştır.

Yukarıda da ifade edildiği gibi yoksullukla mücadelede çok çeşitli araçlar bulunmaktadır. Ancak bu araçlar içerisinde özellikle sosyal yardımlar oldukça yaygındır. Sosyal yardımlar, temel ihtiyaçlarını karşılayabilme olanaklarından yoksun olan kişilere yönelik bir sosyal güvenlik yöntemidir (SYDGM, 2006). Sosyal yardımlar kalıcı çözüm getirmeye yönelik uygulamalar değildir. Bu yardımlarda amaç, temel ihtiyaçlarını bile karşılamada zorlanan bireylerin yoksulluğunun hafifletilmesi ve geçici olarak giderilmesidir (Güneş, 2012). Bu doğrultuda sosyal yardımlar genellikle barınma, yakacak, gıda, giysi, eğitim, sağlık vb. temel ihtiyaçların karşılanması şeklindedir. Yardımlar, doğrudan nakit yardımı olacağı gibi dolaylı olarak temel ihtiyaçların karşılanması şeklinde de olabilir.

Sosyal yardımlara bakış açısı, uygulanış biçimi, organizasyon yapısı ve yarattığı etkisi ülkeden ülkeye farklılık göstermektedir (Gough, 2010). Farklılığı yaratan en önemli neden ise ülkelerin sahip olduğu sosyal, kültürel ve ekonomik özelliklerdir. Sonuçta her ülke kendine has bir sosyal yardım düzenlemesine gitmektedir.

Tüm dünya gibi ülkemizde de yoksulluk ciddi bir sorundur. Bu nedenle hem kamu hem de özel birçok kurum ve kuruluş yoksulluk ile mücadele amaciyla çalışmalar yapmakta ve sosyal yardımlarda bulunmaktadır. Bu kurum ve kuruluşlar 
arasında Aile Çalışma ve Sosyal Hizmetler Bakanlığı, Sağlık Bakanlığı, Millı̂ Eğitim Bakanlığ1 vb. merkezi teşkilat ile yerel yönetimler, Vakıflar Genel Müdürlüğü ve Türk Kızılay'ı önemli bir yere sahiptir.

Aile, Çalışma ve Sosyal Hizmetler Bakanlığı bünyesindeki Sosyal Yardımlar Genel Müdürlüğü ile yoksullukla mücadelede ülkenin en önemli yapısını oluşturmaktadır. Söz konusu Müdürlük, Sosyal Yardımlaşma ve Dayanışma Vakfı (SYDF) aracılığıyla tüm il ve ilçelerde teşkilatlanmıştır. Bakanlığın aile yardımları, yaşlı ve engellilere yönelik yardımları, eğitim-sağlık yardımları vb. sosyal yardım programları bulunmaktadır (https://ailevecalisma.gov.tr/sygm). Bireylerin sosyal ve ekonomik hayata katılımlarının arttırılması, yoksulluk ve sosyal dışlanmanın önüne geçebilmek için bakanlığın fon kaynakları ile yaptığı proje destek programları da mevcuttur.

Ülkemizde Millî Eğitim Bakanlığı maddi açıdan sıkıntı çeken bireylere burs ve öğrenim kredisi vermektedir. Aynı zamanda nüfusun en yoksul \%6'lik kesiminde yer alan ve ekonomik koşullar nedeni ile çocuklarını okula gönderemeyen ailelere çocuklarının okula devam etmeleri şartıyla eğitim yardımları yapmaktadır (https://ailevecalisma.gov.tr/sygm/programlarimiz/sosyalyardimprogramlarimi z). Sağlık Bakanlığı da ödeme gücü bulunmayan bireylere sağlık hizmeti imkânı sunmaktadır.

Merkezi yönetimin yanı sıra yerel yönetimler de kendi belediye sinırları içerisinde yaşayan yoksul vatandaşlara yönelik yardım ve destek programları düzenlemektedir. Bu doğrultuda yoksul bireylere gıda yardımı, giyecek, yakacak ve eşya yardımı yapmaktadır.

Vakıflar Genel Müdürlüğü (VGM) ise muhtaç aylığı, VGM bursları, vakıf evi hizmetleri, aşevi ve kuru gıda yardımı gibi sosyal hizmetleri yerine getirerek yoksul bireylere yardım etmektedir. Yoksullukla mücadelede Kızılay'ın etkinliği de yadsınamayacak ölçüdedir. Kızılay sosyal dayanışmayı artırmak ve muhtaç bireylere (gıda, barınma ve sağlık hizmetleri) yardım sağlamak için kurulan gönüllü sosyal hizmet kuruluşudur. Bunun yanı sıra Kızılay uluslararası yardım, afet, kan, sosyal hizmetler, eğitim vb. alanlarda da etkin bir kuruluş niteliğindedir (https://www.kizilay.org.tr/neler-yapiyoruz).

\section{Erzurum'da Kadınların Yoksullukla Mücadelesinde Sosyal Yardımların Rolü}

\subsection{Literatür Özeti}

Türkiye'de yoksulluk ve sosyal yardımlarla ile ilgili çalışmaları genel olarak ikiye ayırmak mümkündür. Birinci grupta ulusal ya da uluslararası nitelikteki kurum ve kuruluşlar (Türkiye İstatistik Kurumu, Sosyal Yardımlaşma ve Dayanışma Genel Müdürlüğü, Dünya Bankası, Birleşmiş Milletler Kalkınma Programı vb.) tarafından yapılan çalışmalar yer almaktadır. Bu çalışmalarda 
istatistiki veriler ile durum tespitinin yapılması söz konusudur. İkinci grup çalışmalar ise bilimsel araştırmalardır. Bu araştırmalarda yoksulluk ve sosyal yardımlar arasındaki ilişki çoğunlukla teorik olarak tartışılmaktadır. Bununla birlikte sosyal yardımları düzenleyen ve dağıtan kurumlar ile bu yardımlardan yararlanan kişiler üzerine yapılmış ampirik araştırmalarda mevcuttur. Bilimsel araştırmaların odak noktasında sosyal yardımlara bakış açısı, yardımların organizasyon yapısı, karşılaşılan problemler ve yarattığı etkiler gibi konular yer almaktadır.

Türkiye'de sosyal yardımlar, genellikle hayırseverlik anlayışına dayalı bir sistem ile bütünleşmiştir ve bu durum literatürde tartışlan önemli konulardan biridir. Aslında Türkiye 1960'lardan itibaren sosyal devlet anlayışını anayasal olarak kabul etmiş ve takip eden yıllarda yardımları düzenleyecek organizasyon yapıları oluşturmuştur. Özellikle SYDV aracılığıyla tüm ülkeye il ve ilçe boyutunda yaygınlaşmıştır. Ancak günümüzde Türkiye'de sosyal yardımlar doğrudan kamu kaynaklarından finanse edilmek ile birlikte, yardımların gönüllülük esasına dayandığı da görülmektedir (Metin, 2011).

Buğra (2011) bu bakış açısını "iç içe geçmiş devlet-hayır kurumu ilişki" modeli olarak ifade etmektedir. Modelde devlet sosyal yardımları gönüllük esasına dayandırarak biçimlendirmektedir. Güneş (2012) böyle bir anlayışın devletin yoksulluğu önleme politikalarını kısmi ve süreksiz yaptığını, böylece sorunlu bir alan yaratıldığını iddia etmektedir. Bu sorunlu alan içerisinde yetkili kamu kurumu tam olarak bilinememekte ve bunun sonucunda koordinasyon eksikliği oluşmaktadır. Ayrıca özel sektör ve sivil toplum kuruluşlarıyla işbirliği yetersiz kalmaktadır (Çakar ve Yılmaz, 2010). Ancak yardımlar konusundaki tek sorun bu değildir. Özellikle ampirik araştırmalar sosyal yardımların çok çeşitli problemlere sahip olduğunu ve bu nedenle etkinlik kaybına uğradığını vurgulamaktadır (İlter, 2009; Apaydın, 2011; Uçar, 2011; Aca, 2018; Gülşen; 2019).

Literatürde yoğun olarak tartışılan bu problemlerden bazıları yoksul bireylerin bilgilerinin bulunduğu bir veri tabanının eksikliği, yardım miktarlarının yetersizliği, istihdama teşvik eden sosyal yardım programlarının yetersizliği, sosyal hizmet temelli çalışmalara verilen desteğin yetersizliği, sosyal yardımlar için nesnel bir yoksulluk kriterinin olmayışı, yardımdan faydalananların yardımları suiistimali ve yardımların ulaştığı nüfusun kısıtlılığıdır (Çakar ve Yılmaz, 2010: 3-4).

Sosyal yardımlar sosyal güvenlik sisteminin bir tamamlayıcısı olarak görülmekte ve sistem dışında kalan bireylere dönük tasarlanmaktadır (Koray, 2000). $\mathrm{Bu}$ nedenle düzenli bir işi olan sosyal güvenceye sahip kişiler, yardımların kapsamına girememektedir. Ancak Türkiye'de 2019 Eylül ayı yoksulluk sınırı dört kişilik bir hane için yaklaşık 6.725 € olarak hesaplanmıştır (TÜRK-İŞ, 2019). Bu sonuç Türkiye' de düzenli bir işi olan ve sosyal güvenlik sistemi içerisinde yer alan büyük 
bir yoksul kitlenin var olduğunu göstermektedir. Bu nedenle çalışanların dışlandığı bir sosyal yardım yaklaşımının, yoksullukla mücadelede yeterince faydalı olamayacağı kabul edilmektedir (Güneş, 2012). Diğer taraftan kıt olan sosyal yardımlar, yardıma başvuran kişi sayısı arttıkça daha fazla yetersiz kalmaktadır. Bu nedenle yoksulluğun ve yoksulun nesnel tanımlamasının yapılması gerekmektedir. Böylece doğrudan kaynak transferi olan sosyal yardımlar doğru kişilere ulaştırılabilecektir (Apaydın, 2011).

Literatürde önemli tartışma konularından biri de yardımların yoksullara yansımasıdır. Çalışmalarda Türkiye' de sosyal yardımların gerekliliğ̆ine ilişkin genel bir kanaat bulunmakta ve yardım politikalarının devamlılı̆g 1 savunulmaktadır. Sosyal yardımların yoksulluğun çözümü için yeterli olmadığı, ancak yoksulluğun kontrol edilmesinde önemli etkiler oluşturduğu belirtilmektedir. Örneğin; Buğra ve Keyder (2002) belirli bir gelir seviyesinin altında gelire sahip yoksullara sağlanacak ek gelir desteğinin onların daha istikrarlı yaşamalarına ve geleceğe güven ile bakmalarına imkân sağlayacağını belirtmektedir. Apaydın (2011) küreselleşen dünya ile birlikte, devletlerin yoksullukla mücadeleyi sosyal devlet olmanın gereği saydıklarını, bu mücadelenin yönteminin de sosyal destekler olduğunu ileri sürmektedir. Yaşar ve Açıkgöz (2011) ise kent varoşlarına vurgu yaparak yoksul kişilerin yoğunlaştığ 1 bu alanlarda yapılacak sosyal yardım ve hizmetlerin sosyal ve siyasi bütünleşmeyi sağlayacağını ifade etmektedir.

Yukarıda belirtilen olumlu görüşlere karşın sosyal yardımların bizzat kullanıcılarının hayatına yansımasına ve etkilerine ilişkin sınırlı bilgi mevcuttur. Çünkü Türkiye'deki sosyal yardım araştırmaları çoğunlukla tedarikçi kurumlara odaklanarak bu kurumları örneklemlerine dâhil etmektedir.

Yardımlardan faydalanan kişiler üzerine yapılan araştırmaların sonuçları farklılık göstermektedir. Bir kısım çalışmalar, sosyal yardımların yoksulların hayatında herhangi bir etki oluşturmadığını belirtirken diğerleri ise yardımların kalıcı çözümler oluşturamamakla birlikte, yoksulların hayatına olumlu katkı yaptığını vurgulamaktadır. Örneğin; Aca (2018) tarafından yapılan araştırmada Bursa Valiliği'nin düzenlediği sosyal yardımlar ele alınarak bu yardımlardan beklenen faydalar ve yardım alanların refahındaki yükselme durumu araştırılmıştır. Araştırmada kamu desteği ile yapılan sosyal yardımların beklenen amaca ulaşamadığı ve beklenen sosyal refah etkisini gerçekleştiremediği sonucuna ulaşılmıştır.

Kula ve Kula (2007) ise Afyonkarahisar'da yer alan Sivil Toplum Kuruluşlarının (STK) kadın yoksulluğu ile mücadeledeki rollerini ve gerçekleştirdikleri faaliyetlerin yoksulluğa etkisini incelemişlerdir. Sonuçlara göre STK'nın kadın yoksulluğu ile mücadelede en çok tercih ettiği yöntem ayni ve nakdi yardımlar düzenlemek ve 
dağıtmaktır. Ancak bu yöntem geçici çözümler yaratmakta, kadınların sorunlarını kalıcı olarak çözümleyememektedir.

Apaydın (2011) tarafından yapılan araştırmada Altındağ SYDV aracılığıyla yapılan sosyal yardımların yoksullukla mücadeledeki rolü irdelenmiştir. Sonuçlara göre sosyal yardımlar; yardım alanlar üzerindeki sosyo-psikolojik etkiler ve yapılan yardımların yarattığı bağımlılık gibi konularda problemlere sahiptir. Bununla birlikte sosyal yardımlar, kişilere yoksullukla mücadelede yine de önemli bir destek sağlamaktadır.

İlter (2009) araştırmasında sosyal yardımların öneminden bahsederek Türkiye' de yoksulluğun kuşaktan kuşağa aktarılmadığı sonucuna ulaşmıştır. Uçar (2011) ise çalışmasında sosyal yardımların kadın yoksulluğunu önlemedeki rolünü araştırmıştır. Bu amaçla SYDV'den yardım alan 13 kadınla bir anket araştırması yürütmüştür. Araştırma sonucunda cinsiyet konusunda eğitimler ile farkındalığın artırılmasının toplumsal bütünleşme sağlayacağı ve kadınların konumlarını iyileştireceği sonucuna ulaşılmıştır. Böylece kadınların sosyal yardımlara bağımlılığı da azaltılacaktır.

Bir başka çalışmada Alptekin ve Aksan (2010) Konya'da resmi kurumlar ve STK'lardan yardım alan 500 yoksul kadın ile bir araştırma yürütmüşlerdir. Yoksulluğu kader olarak gören kadınlar sosyal yardımların hanelerinin geçiminde önemli bir yere sahip olduğunu belirtmişlerdir. Güneş (2014) ise Eskişehir'de 300 kadının katılımıyla yaptığı araştırmasında hanelerde erkeğin çalışmamasının sosyal yardımlara bağımlılığı artırdığını, ayrıca kadınları da enformel sektörlerde çalışmaya yönlendirdiği sonucuna ulaşmıştır.

\subsection{Araştırmanın Amacı, Kapsamı ve Hipotezleri}

Araştırmada erkekler ile kıyaslandığında göreceli olarak yoksulluğu daha derinden hisseden kadınların yoksulluklarının boyutlarını, yoksulluğa karşı verdikleri mücadeleyi ve bu mücadelede özellikle sosyal yardımların rolünü tespit etmek amaçlanmaktadır. Sosyal yardımlara başvuru süreci, alınan yardımların türleri ve oluşturduğu etkiler araştırmanın temel konusu olmakla birlikte, kadınların yardımına başvurabileceği kendisinin ve eşinin ailesi, özel şahıs/vakıflar ile mahalleli gibi alternatif yollar da araştırmada irdelenmiştir.

Araştırma, Erzurum il merkezine bağlı üç ilçede (Yakutiye, Aziziye ve Palandöken) ikamet eden ve görece olarak daha düşük gelir grubunda yer alan kadınlar ile yürütülen bir anket çalı̧̧asıdır. Araştırmanın kapsamı iki kıstasa dayanmaktadır. Birincisi katılımcıların kadınlardan oluşması, diğeri ise toplam hane gelirine bir üst limit belirlenmesidir.

Kadınların sadece çalışma kapsamına dâhil edilmesinin altındaki en önemli neden toplumdaki genel kanaattir. "Toplumsal bakış açısında kadınların yoksul olması ve yardım istemesi ayıplanmazken erkeklerin yoksul olması, başkasının 
yardımına muhtaç olması ayıplanmaktadır. Bu nedenle yoksul ailelerde sosyal yardımlar, erkeklere göre genellikle kadınlar tarafından alınmakta ve kadınlar yardımların peşinden koşmaktadır" (Şener, 2010: 18). Bu nedenle araştırma kadınlar ile sinırlı tutulmuştur.

Hane geliri belirlenirken TUIK' in 2017 yılı eşdeğer hanehalkı kullanılabilir fert gelirine göre sıralı yüzde $10^{\prime}$ luk gruplar itibariyle ilk \%10'luk dilimde yer alan hanehalkı kullanılabilir fert gelir dağılımı dikkate alınmıştır. Bu veriye göre Erzurum alt bölgesinde \%10'luk dilimdeki hane geliri yaklaşık ortalama 5.600 €́dir. $\mathrm{Bu}$ veriye dayandırılarak toplam hane geliri için 5500 £ eşik değer belirlenmiş ve bu değerin altında hane gelirine sahip kadınlar ile araştırma yürütülmüştür.

Araştırmanın hipotezleri iki temel husus üzerinden şekillendirilmiştir. $\mathrm{Bu}$ hususlar katılımcıların kendilerini yoksul hissetmeleri ve sahip oldukları toplam hane geliridir. Araştırmada bu iki husus ile yoksul kadınların farklı kişi/kurumlardan maddi yardım alması arasında anlamlı bir farklılık olup olmadığı incelenmektedir.

Araştırmanın hipotezleri Tablo 1'de verilmektedir.

Tablo 1: Araştırmanın Hipotezleri

$\mathbf{H}_{\mathbf{1}}$ : Katılımcıların maddi yardım alması ile kendini yoksul hissetmesi arasında anlamlı bir farklılık vardır.

$\mathbf{H}_{1 \mathrm{~A}}$ Katılımcların kendi ailesinden maddi yardım alması ile kendisini yoksul hissetmesi arasında anlamlı bir farklılık vardır.

$\mathbf{H}_{1 \mathrm{~B}}$ Katılımcıların eşinin ailesinden maddi yardım alması ile kendisini yoksul hissetmesi arasında anlamlı bir farklılık vardır.

$\mathbf{H}_{1 \mathrm{C}}$ Katılımcıların mahalleliden maddi yardım alması ile kendisini yoksul hissetmesi arasında anlamlı bir farklılık vardır.

$\mathbf{H}_{1 \text { D }}$ Katılımcıların özel şahıs/vakıflardan maddi yardım alması ile kendisini yoksul hissetmesi arasında anlamlı bir farklılık vardır.

$\mathbf{H}_{1 \mathrm{E}}$ Katılımcıların resmi kurum/kuruluşlardan maddi yardım alması ile kendisini yoksul hissetmesi arasında anlamlı bir farklılık vardır.

$\mathbf{H}_{2}$ : Katılımcıların maddi yardım alması ile toplam hane geliri arasında anlamlı bir farklılık vardır.

$\mathbf{H}_{2 \mathrm{~A}}$ Katılımcıların kendi ailesinden maddi yardım alması ile kendisini yoksul hissetmesi arasında anlamlı bir farklılık vardır.

$\mathbf{H}_{2 B}$ Katılımcıların eşinin ailesinden maddi yardım alması ile kendisini yoksul hissetmesi arasında anlamlı bir farklılık vardır. 
$\mathbf{H}_{2 \mathrm{C}}$ Katılımcıların mahalleliden maddi yardım alması ile toplam hane geliri arasında anlamlı bir farklılık vardır.

$\mathbf{H}_{2 D}$ Katılımcıların özel şahıs/vakıflardan maddi yardım alması ile toplam hane geliri arasında anlamlı bir farklılık vardır.

$\mathbf{H}_{2 \mathrm{E}}$ Katılımcıların resmi kurum/kuruluşlardan maddi yardım alması ile toplam hane geliri arasında anlamlı bir farklılık vardır.

\subsection{Veri Toplama Araç ve Teknikleri}

Çalışmada veri toplamak için anket araştırması yürütülmüştür. Anket kapalı uçlu sorulara dayanmaktadır. Bununla birlikte konuya dair daha ayrıntılı bilgi edinmek amacıyla katılımcılara açık uçlu sorular da yönlendirilmiştir. Anket şablonunun oluşturulması için ikincil veri kaynaklarından (Batur, 2011; Emir, 2009; Yusufoğlu, 2010; Öztürk, 2008; Berber, 2016) yararlanılmıştır. Ayrıca araştırma konusu ile ilgili yasal düzenleme ve uygulamalar da incelenerek anket soruları çeşitlendirilmiş ve özellikle yüz yüze görüşmelerde açık uçlu sorulara yön verebilmek için kullanılmıştır.

Anket iki kısımdan oluşmaktadır. Birinci kısımda katılımcının demografik özellikleri ve hanehalkının yapısını tespit etmeye yönelik sorular yer almaktadır. İkinci kısımda ise katılımcıların herhangi bir maddi destek alıp almadıklarını, alıyorlarsa bu yardımların niteliğini ve aile ekonomisine katkısını tespit etmeye yönelik sorular bulunmaktadır. Bu kısımda özellikle katılımcıların sosyal yardım kuruluşlarından haberdarlıklarının ve yararlanıp yararlanmadıklarının belirlenmesi ile bu kuruluşlara yönelik duygu ve düşüncelerinin tespit edilmesi amaçlanmaktadır.

Anket sorularında katılımcıların anlayabilirlik oranını artırabilmek için mümkün olduğunca sade ve kısa ifadelere yer verilmiştir. Ayrıca cevaplandırmada likert ölçeği yerine daha basit olan evet ve hayır şeklinde ikili bir tercih sunulmuştur.

Anketlerin uygulanmasına geçilmeden önce pilot çalışma gerçekleştirilmiş ve eksiklikler tespit edilerek ankete nihai şekil verilmiştir. Anketin uygulanması MartMayıs 2019 tarihinde gerçekleştirilmiştir. Bilgilerin tasnif edilmesi ve analizlerinde SPSS 21.0 (Statistical Program For Social Sciences) bilgisayar paket programından yararlanılarak istatistiki analizler yapılmıştır.

\subsection{Araştırmanın Ana kütlesi ve Örneklem Seçimi}

Araştırmanın ana kütlesini Erzurum il merkezine bağlı üç ilçede (Yakutiye, Palandöken ve Aziziye) ikamet eden ve görece olarak daha düşük gelir grubunda (ilk \%10'luk dilimde) yer alan kadınlar oluşturmaktadır.

Yoksulluk tanımlanması ve ölçülmesi zor bir kavram olduğu için yoksul insanların tespit edilmesi de oldukça zordur. Bu kısıttan dolayı ana kütle sayısı net olarak hesaplanamamaktadır. Ancak yaklaşık bir ana kütle sayısı belirleyebilmek 
için TUiK'e ait 2017 yılı nüfus, hanehalkı ve hanehalkı kullanılabilir gelir verilerinden yararlanılmıştır. Bu verilerin yardımıyla Erzurum il merkezinde ilk $\% 10$ 'da yer alan hane sayısı yaklaşık olarak 6382 olarak hesaplanmıştır. Her hanede de en az bir kadın olduğu varsayılarak Erzurum il merkezinde \%10'luk dilimde yoksul kadın sayısı yaklaşık 6382 olarak kabul edilmiştir. Bu sayı araştırmanın evrenini oluşturmaktadır. \%5 hata payına göre araştırmanın örneklem sayısı ise 362 olarak hesaplanmıştır (http:// www.surveysystem.com/ sscalc.htm ).

Örnekleme ulaşabilmek için Erzurum'daki Sosyal Yardımlaşma Kurumları ile görüşülmüş ve yardımlardan faydalananların çoğunlukla yaşadıkları mahalleler tespit edilmiştir. Araştırmada sadece sosyal yardım alan kadınlara değil, yardımlardan yararlanmayan kadınlara da ulaşmak hedeflenmiştir. Bu nedenle kurumlardan sadece genel bilgi alınmış ve kentin göreceli olarak daha yoksul hanelerinin yaşadığı mahalleler belirlenmiştir.

Mahalleler tespit edildikten sonra sosyal ilişkiler ve ağlar kullanılarak kartopu yöntemi ile 200 kadın katılımcıya ulaşılmış ve yüz yüze görüşmeyle anket süreci tamamlanmıştır. "Kartopu örneklem, araştırma devam ederken eklenen olaylardan veya deneklerden oluşur. Bu örneklem bilinebilir ve ulaşılabilir bir veya birkaç denek veya olaya bağlı olarak başlar. Bu teknik, özellikle alışılmış biçimde diğerlerini etkileyen kişilerin olduğu alt-kültürlerin örneklenmesi için kullanılır" (Özen ve Gül, 2007: 413).

\subsection{Araştırmanın Bulguları ve Tartışma}

Araştırmada öncelikle ankette yer alan soruların güvenirlilik analizi Cronbach's Alfa Güvenirlilik Katsayısı kullanılarak yapılmıştır. Cronbach's alfa, modellerin iç tutarlılığının ölçüsüdür (Yıldız ve Uzunsakal, 2018:19). Yapılan analiz sonucu Cronbach's Alfa değeri 0,707 olarak tespit edilmiştir.

Araştırmada her bir sorunun frekans dağılımı incelenmiş ve hipotezler $x^{2}$ bağımsızlık testi ile analiz edilmiştir. İki değişken arasındaki ilişkiyi belirleyen $\chi^{2}$ bağımsızlık testi, parametrik olmayan test yöntemlerinden biridir. Test, verilerin normal dağılım özelliği göstermemesi veya homojen olmaması halinde kullanılmaktadır (Eymen, 2007: 148). Araştırmada bu testin seçilmesinin nedeni verilerin yapılan analizler sonucunda homojen (Homojen Vary. Testi: $p>0,05)$, ancak normal dağılım (One-Sample Kolmogorov-Smirnov Test: $\mathrm{p}<0,05)$ göstermemesidir.

Tablo 2'de katılımcıların demografik özellikleri verilmektedir. Buna göre katılımciların \%30'u 35-44, \%25'i 45-54 ve \%18,0'1 25-34 yaş aralığında yer almaktadır. Doğum yerleri incelendiğinde katılımcıların \%56,0'ının (112 kişi) Erzurum il merkezi doğumlu olduğu görülmektedir. \%44,0' 1 (88 kişi) ise Erzurum il merkezine Erzurum'un diğer ilçelerinden ya da çevre illerden göç etmiştir. Göç etmelerinin başlıca nedeni evliliktir. Eğitim durumlarına ait dağılımda katılımcıların $\% 16,0^{\prime} 1$ okuryazar değil, $\% 43,5$ 'i ilkokul, $\% 10,0^{\prime}$ 1 okuryazar ve $\% 4,0^{\prime} 1$ üniversite 
mezunudur. Üniversite mezunu katılımclar bekâr olup yoksul hanelerde yaşamaktadır. Ayrıca bu katılımcılar iş aradıklarını, ancak eğitimleri doğrultusunda iş bulamadıklarını belirtmişlerdir. Medeni durumları açısından katılımcıların, \%62,0'1 resmi nikâhlı ve \%17,5'i bekârdır. \%4,5'i ise boşanmıştır. Boşanmış katılımcıların önemli bir kısmı geçim sıkıntısı nedeniyle evliliklerini sonlandırdıklarını belirtmişlerdir.

Tablo 2: Katılımcıların Demografik Özellikleri

\begin{tabular}{|c|c|c|c|}
\hline Özellikler & & $\mathbf{N}$ & $\%$ \\
\hline \multirow{7}{*}{ Yaş } & $15-24$ & 33 & 16,5 \\
\hline & $25-34$ & 36 & 18,0 \\
\hline & $35-44$ & 60 & 30,0 \\
\hline & $45-54$ & 50 & 25,0 \\
\hline & $55-64$ & 10 & 5,0 \\
\hline & 65 ve üstü & 11 & 5,5 \\
\hline & Toplam & 200 & 100,0 \\
\hline \multirow{3}{*}{ Doğum Yeri } & Erzurum & 112 & 56,0 \\
\hline & Diğer & 88 & 44,0 \\
\hline & Toplam & 200 & 100,0 \\
\hline \multirow{8}{*}{$\begin{array}{l}\text { Eğitim } \\
\text { Durumu }\end{array}$} & Okuryazar Değil & 32 & 16,0 \\
\hline & Okuryazar & 21 & 10,5 \\
\hline & İlkokul & 87 & 43,5 \\
\hline & İlköğretim & 16 & 8,0 \\
\hline & $\begin{array}{l}\text { Mesleki/Tekn. } \\
\text { Lise }\end{array}$ & 19 & 9,5 \\
\hline & Genel Lise & 17 & 8,5 \\
\hline & Üniversite & 8 & 4,0 \\
\hline & Toplam & 200 & 100,0 \\
\hline & Bekâr & 35 & 17,5 \\
\hline
\end{tabular}




\begin{tabular}{llcc}
\hline $\begin{array}{l}\text { Medeni } \\
\text { Durum }\end{array}$ & $\begin{array}{l}\text { Evli-Resmi } \\
\text { Nikâhlı }\end{array}$ & 124 & 62,0 \\
\cline { 2 - 4 } & $\begin{array}{l}\text { Evli-İmam } \\
\text { Nikâhlı }\end{array}$ & 8 & 4,0 \\
\cline { 2 - 4 } & Eşi ölmüş & 24 & 12,0 \\
\cline { 2 - 4 } & Boşanmış & 9 & 4,5 \\
\hline & Toplam & $\mathbf{2 0 0}$ & $\mathbf{1 0 0 , 0}$ \\
\hline
\end{tabular}

Anketin yapıldığı esnada katılımcıların \% 87,5 (178 kişi)'si çalışmadıklarını ifade etmiştir. Çalışmadığını belirten katılımcıların iş dünyasına dâhil olmama/ayrılmalarında etkili olan başlıca nedenler kendi tercihleri ile çalışmak istememeleri $(\% 22,9)$, eğitim yetersizliği $(14,9)$ ve uygun iş bulamama $(14,3)^{\prime}$ dür. Çalıştığını belirten 7 kadın kamu ya da özel sektörde işçi olarak istihdam edilmektedir. Bu kadınlar sosyal güvenceye de sahiptir. Diğer çalışan 18 kadın ise enformel sektöre ait farklı iş kollarında (gündelikçi, çocuk bakıcısı vb.) çalışmaktadır. Çalışan katılımcıların $\% 24,0^{\prime}{ }_{1} 500$ も ve altı aylık gelir elde ettiklerini söylerken \%20,0'1 501-1000 も, \%24,0'1 1001-1500 も, \%16,0'1 1501-2000 も ve \%16,0'1 2001-2500 も aralığında gelir elde ettiğini belirtmiştir. Katılımcıların çalışma durumlarına ilişkin bilgiler Tablo 3'de verilmektedir.

Tablo 3: Katılımcıların Çalışma Durumlarına İlişkin Bilgiler

\begin{tabular}{llcc}
\hline Çalışma Durumu & N & \% \\
\hline Hiç çalışmamış olanlar & 166 & 83,0 \\
\hline Daha önce çalışıp şu an çalışmayanlar & 9 & 4,5 \\
\hline \multirow{2}{*}{\begin{tabular}{l} 
Folışanlar \\
\cline { 2 - 4 }
\end{tabular}} & $\begin{array}{l}\text { Enformel Sektörde çalışanlar } \\
\text { çalışanlar }\end{array}$ & 7 & 3,5 \\
\hline Toplam & Sektörde & 18 & 9,0 \\
\hline
\end{tabular}

Katılımcıların yaklaşık \%80'inden fazlası çekirdek aile yapısına sahiptir. Kadınların \%78,5'i (157 kişi) çocuk sahibidir. Bu kadınların \%21,0'ının 3 çocuğu varken \%15,5'inin 5 ve üstü çocuğu vardır. Katılımcıların \%75,2'sinin (118 kişi) çocukları öğrencidir. 125 kadının $(\% 79,6)$ çocukları herhangi bir işte çalışmazken 32 $(\% 20,4)$ kadının çocukları çalışmaktadır.

Anketin yapıldı̆̆ı anda evli (resmi ya da dini nikâhlı) olduğunu belirten kadınların \%77,3 (102 kişi)'nin eşi çalışırken \%22,7 (30 kişi)'nin eşi işsizdir. Eşi 
çalışan katılımcıların \%34,3'ünün eşi özel sektörde işçiyken \%17,6'sınınki kamuda iş̧̧idir. Katılımcıların eşlerinin \%35,3’ü 1501-2000 € ve \%26,5' i 2001-2500 € aralığında gelir elde etmektedir. Eğitim durumuna göre katılımcıların eşlerinin \%59,0' 1 ilkokul, $\% 13,5$ 'i ilköğretim ve \%12,8'i lise mezunudur.

Hanesinde en az bir sigortalı çalışanın olduğu katılımcıların oranı \%42,5 (85 kişi) iken hiç sigortalı çalışanın olmadığı katılımcı oranı \%57,5 (115)'dir.

Tablo 4'de katılımclların toplam hane gelirlerine ait bilgiler sunulmaktadır.

Tablo 4: Toplam Hane Gelirine ait Bilgiler

\begin{tabular}{lrr}
\hline $\begin{array}{l}\text { Gelir } \\
\text { Aralığı }\end{array}$ & N & \% \\
\hline$\leq 750 €$ & 29 & 14,5 \\
\hline $751-1500 €$ & 42 & 21,0 \\
\hline $1501-2250 €$ & 67 & 33,5 \\
\hline $2251-3000 €$ & 40 & 20,0 \\
\hline $3001-3750 €$ & 15 & 7,5 \\
\hline $3751-4256 €$ & 7 & 3,5 \\
\hline Toplam & $\mathbf{2 0 0}$ & $\mathbf{1 0 0 , 0}$ \\
\hline
\end{tabular}

Toplam hane geliri üst limiti 5.500 € olarak belirlenmesine rağmen 4.000 £'nin üzerinde hane gelirine sahip katılımcı araştırmada bulunmamaktadır. Tablo 4'e göre katılımciların \%33,5'inin 1501-2250 £, \%21'inin 751-1500 £ ve \%20'sinin 2251-3000 £ arasında toplam hane geliri mevcuttur. Katılımclar sahip oldukları hane gelirini en çok gida $(\% 70,5)$ borç yükü $(\% 11,0)$ ve faturalara $(\% 10,5)$ harcamaktadır.

Katılımcılara sahip oldukları koşullar ile kendilerini yoksul hissedip hissetmedikleri sorulduğunda \%78'inin (156 kişi) kendini yoksul hissettiği, \%22'sinin (44 kişi) hissetmediği cevabı alınmıştır. Kendini yoksul hisseden katılımcılar işsizliği $(\% 60,9)$, düşük ücreti $(\% 14,7)$ ve eğitim yetersizliğini $(\% 10,3)$ yoksulluklarının başlıca nedenleri olarak görmektedir.

Tablo 5'de katılımcıların şahıs ya da kurum/kuruluşlardan (kendi ailesi, eşinin ailesi, mahalleli, özel şahıs/vakıflar ve resmi kurum/kuruluşlar) yardım alıp almadıklarına dair dağılımlar verilmektedir. 
Tablo 5: Katılımcıların Şahıs ya da Kurum/Kuruluşlardan Yardım Alma

Durumları

\begin{tabular}{|c|c|c|c|}
\hline & Seçenek & $\mathbf{N}$ & $\%$ \\
\hline \multirow{3}{*}{$\begin{array}{l}\text { Kendi ailesinden yardım } \\
\text { alma }\end{array}$} & Evet & 39 & 19,5 \\
\hline & Hayır & 161 & 80,5 \\
\hline & Toplam & 200 & 100,0 \\
\hline \multirow{4}{*}{$\begin{array}{l}\text { Eşin ailesinden } \\
\text { alma }\end{array}$} & Evet & 21 & 10,5 \\
\hline & Hayır & 144 & 72,0 \\
\hline & Boş & 35 & 17,5 \\
\hline & Toplam & 200 & 100,0 \\
\hline \multirow{3}{*}{ Mahalleliden yardım alma } & Evet & 4 & 2,0 \\
\hline & Hayır & 196 & 98,0 \\
\hline & Toplam & 200 & 100,0 \\
\hline \multirow{3}{*}{$\begin{array}{l}\text { Diğer şahıs/vakıflardan } \\
\text { yardım alma }\end{array}$} & Evet & 22 & 11,0 \\
\hline & Hayır & 178 & 89,0 \\
\hline & Toplam & 200 & 100,0 \\
\hline \multirow{3}{*}{$\begin{array}{l}\text { Kurum ve kuruluşlardan } \\
\text { sosyal yardım alma }\end{array}$} & Evet & 133 & 66,5 \\
\hline & Hayır & 67 & 33,5 \\
\hline & Toplam & 200 & 100,0 \\
\hline
\end{tabular}

Tablo 5'e göre katılımcıların \%19,5'i kendi ailesinden, \%10,5'i eşinin ailesinden, $\% 2,0^{\prime} 1$ mahalleliden, $\% 11,0^{\prime} 1$ diğer şahıs/vakıflardan maddi yardım almaktadır. Bununla birlikte katılımcıların en fazla yardım almak için başvurdukları yol \%66,5 ile sosyal yardım dağıtan kurumlardır.

Katılımcıların farklı kişi ve kurumlardan yardım alması ile kendini yoksul hissetmesi arasında anlamlı bir farklılık olup olmadığı $\chi^{2}$ bağımsızlık testi ile analiz edilmiştir. 
Tablo 6: Katılımcıların Maddi Yardım Alması ile Kendisini Yoksul Hissetmesi arasındaki İlişkilere ait $\chi 2$ Analiz Sonuçları

\begin{tabular}{lccc}
\hline Karşılaştırılan Değişkenler & $\mathbf{N}$ & $\chi^{\mathbf{2}}$ & $\mathbf{P}$ \\
\hline Kendi ailesinden maddi yardım alması & 200 & 1,087 & 0,297 \\
\hline Eşinin ailesinden maddi yardım alması & 200 & 3,263 & $\mathbf{0 , 0 7 1 ^ { * * }}$ \\
\hline Mahalleliden maddi yardım alması & 200 & 1,151 & 0,283 \\
\hline Diğer şahıs/vakıflardan maddi yardım alması & 200 & 2,401 & 0,121 \\
\hline $\begin{array}{l}\text { Resmi kurum/Kuruluşlardan maddi yardım } \\
\text { alması }\end{array}$ & 200 & 7,069 & $\mathbf{0 , 0 0 8 *}$ \\
\hline
\end{tabular}

* \%5 önem düzeyine göre istatistiki olarak anlamlıdır.

** \%10 önem düzeyine göre istatistiki olarak anlamlıdır.

Tablo 6' ya göre kişinin kendi ailesi, mahalleli ve diğer şahıs/vakıflardan yardım alması ile kendini yoksul hissetmesi arasında istatistiki olarak anlamlı bir ilişki bulunmamaktadır. Buna bağlı olarak $\mathrm{H}_{1 \mathrm{~A}}, \mathrm{H}_{1 \mathrm{C}}$ ve $\mathrm{H}_{1 \mathrm{D}}$ hipotezleri reddedilmiştir.

“ $\mathrm{H}_{1 \mathrm{~B}}$ : Katılımcıların eşinin ailesinden maddi yardım alması ile kendisini yoksul hissetmesi arasında anlamlı bir farklılık vardır." hipotezi istatistiki olarak \%10 önem düzeyinde kabul edilmiştir. İlgili sonuç incelendiğinde kendini yoksul hisseden katılımcıların (156 kişi) \%90'ının eşinin ailesinden yardım almadığı, sadece \%10'unun yardım aldığı görülmektedir. Buna karşılık kendini yoksul hisseden kadınların \%18'i kendi ailesinden ve \%13'ü diğer şahıs/vakıflardan yardım kabul etmektedir. Kendini yoksul hisseden katılımcıların en düşük oranda yardımlarına başvurdukları ise \%3 ile kendi mahallelerindeki insanlardır.

Kentli yoksul insanlar genellikle gecekondu bölgelerinde ve kent içi yoksul mahallelerde bir arada yaşamaktadır (Adaman ve Keyder, 2006). Benzer ekonomik koşullara sahip olan yoksul mahalle sakinlerinin birbirlerine maddi olarak destek sağlaması zorlaşmaktadır. Bu nedenle kendini yoksul hisseden katılımcıların mahallelerinden yardım alma imkânın çok fazla olması beklenmemektedir. Ancak katılımcılar eşlerinin ailesinden de yardım almamakta ya da alamamaktadır. $\mathrm{Bu}$ durumun altında muhakkak ki birçok husus etkilidir. Örneğin; eşinin ailesinin ekonomik koşulları yardım için yeterli gelmeyebilir. Ancak kadınlar kendi ailelerinden ya da yabancı üçüncü kişilerden eşinin ailesine göre daha fazla yardım almaktadır. Bu sonuç, literatürde de yoğun olarak vurgulanan erkeklerin yardım istemekte daha çekingen kaldığı sonucu ile ilişkili olabilir.

Tablo 6' da görüldüğü gibi katılımcıların kendini yoksul hissetmesi ile farklı resmi kurumlardan sosyal yardım alması arasında \%5 önem düzeyinde anlamlı bir 
farklılık tespit edilmiştir. Böylece $\mathrm{H}_{1 \mathrm{E}}$ "Katılımcıların resmi kurum/kuruluşlardan maddi yardım alması ile kendisini yoksul hissetmesi arasında anlamlı bir farklılık vardır." hipotezi kabul edilmiştir Kurum/kuruluşlardan yardım alan kadınların $\% 87,1^{\prime}$ i kendini yoksul hissederken $\% 12,9^{\prime}$ u kendini yoksul hissetmemektedir. Bu sonuca bağlı olarak kendini yoksul hissedenlerin yoğunluklu olarak kurumların sosyal yardımlarına başvurdukları belirtilebilir.

Katılımcıların farklı kişi ve kurumlardan yardım alması ile toplam hane geliri arasındaki ilişkiyi araştırmak amacıyla $\chi^{2}$ bağımsızlık testi yapılmıştır. Sonuçlara göre katılımcıların toplam hane geliri ile eşinin ailesinden, mahalleliden ve diğer kişi/vakıflardan yardım alması arasında ilişki bulunmamaktadır. Bu sonuçlara bağlı olarak $\mathrm{H}_{2 \mathrm{~B}}, \mathrm{H}_{2 \mathrm{C}}$ ve $\mathrm{H}_{2 \mathrm{D}}$ hipotezleri reddedilmiştir. İlgili sonuçlar Tablo 7'de aktarılmaktadır.

Tablo 7: Katılımcların Maddi Yardım Alması ile Toplam Hane Geliri arasındaki İlişkilere ait $\chi 2$ Analiz Sonuçları

\begin{tabular}{llcc}
\hline Karşılaştırılan Değişkenler & N & $\chi^{\mathbf{2}}$ & $\mathbf{P}$ \\
\hline Kendi ailesinden maddi yardım alması & 200 & 26,644 & $\mathbf{0 , 0 0 0 ^ { * }}$ \\
\hline Eşinin ailesinden maddi yardım alması & 200 & 5,341 & 0,376 \\
\hline Mahalleliden maddi yardım alması & 200 & 3,541 & 0,617 \\
\hline Diğer şahıs/vakıflardan maddi yardım alması & 200 & 7,056 & 0,216 \\
\hline $\begin{array}{l}\text { Resmi kurum/Kuruluşlardan maddi yardım } \\
\text { alması }\end{array}$ & 200 & 26,339 & $\mathbf{0 , 0 0 0 *}$ \\
\hline
\end{tabular}

* \%5 önem düzeyine göre istatistiki olarak anlamlıdır.

Tablo 7'ye göre kendi ailesi ve resmi kurum/kuruluşlardan yardım alması ile katılımcının toplam hane geliri arasında ise \%5 önem düzeyinde anlamlı farklılık tespit edilmiştir. Böylece " $\mathrm{H}_{2 \mathrm{~A}}$ : katılımcıların kendi ailesinden maddi yardım alması ile toplam hane geliri arasında anlamlı bir farklılık vardır" ve " $\mathrm{H}_{2 \mathrm{E}}$ : Katılımcıların resmi kurum/kuruluşlardan maddi yardım alması ile toplam hane geliri arasında anlamlı bir farklılık vardır" hipotezleri kabul edilmiştir.

Hanenin toplam geliri azaldıkça kadınların resmi kurum/kuruluşlardan daha fazla sosyal yardım aldıkları görülmektedir. Bu beklenen bir sonuçtur. Çünkü sosyal yardımların öncelikli amacı en temel ihtiyaçlarını bile karşılamakta zorlanan çok düşük gelirli bireylerin yoksulluğunu hafifletmektir. Bu nedenle hane geliri düştükçe insanlar daha fazla sosyal yardımlara yönelmektedir. Ancak katılımcıların hane geliri ile kendi ailelerinden yardım alması arasında böyle bir orantısal dağılım bulunamamıştır. Örneğin 1500 € ve altı geliri olan hanelerde toplam 71 kadının $\% 22$ 'si kendi ailesinden yardım alırken 2251-3000 € aralığında geliri olan kadınların 
(40 kişi) \%42,5'i ailesinin yardımına başvurmaktadır. 3000 モ üstü geliri olan hanelerde ise kadınların (22 kişi) sadece \%9'u kendi ailesinden yardım almaktadır.

2251-3000 ₹ aralığında toplam hane gelirine sahip katılımcılar irdelendiğinde 13 kadının bekâr olduğu belirlenmiştir. Bekâr kadınlar kendi ailelerinden maddi destek alıyor olabilirler. Buna karşılık 22 kadının eşlerinin ağırlıklı olarak özel sektörde asgari ücrete tabi işçi olduğu tespit edilmiştir. Ülkemizde sosyal yardımlar öncelikli olarak sosyal güvenlik sistemi içerisinde yer almayan düşük gelirli kişilere yönlendirilmektedir. Düşük gelirli, ancak sistem içerisinde yer alan kişiler ise yardımlardan çok fazla yararlanamamaktadır. Bunun sonucunda sosyal yardım alamayan kadınlar, kendi ailelerinin yardımlarına ihtiyaç duyuyor olabilir.

"Sosyal yardımlardan nasıl haberdar oluyorsunuz?" sorusuna katılımciların \%75'i eş/dost aracılığıyla cevabını vermiştir. Yaklaşık \%19'u ise medya aracılığıyla yardımlardan haberdar olmaktadır. "Yardımlardan haberdar olmanız için yapılanlar yeterli mi?" sorusuna ise \%72'si hayır cevabını vermiştir.

Erzurum'da farklı kurumlar tarafından verilen sosyal yardımlardan katılımcıların haberdarlıklarına ilişkin bilgiler Tablo 8' de verilmektedir. Buna göre katılımcıların \%95,5'i Vakıflar Genel Müdürlüğü'nün muhtaç yardımından ve $\% 94,0^{\prime}{ }_{1}$ ise kuru gida yardımından yararlanmamaktadır. Benzer şekilde katılımciların \%80,0' 1 belediyenin gida yardımından ve \%95,5'i giysi yardımından faydalanmamaktadır. Ayrıca kadınların 171'i belediyenin çalışmayan vatandaşlara kariyer merkezinde iş bulduğundan haberdar değildir. Katılımcıların \%62,5 Sosyal Yardım ve Dayanışma Vakfı'ndan, $\% 77,0^{\prime} 1$ Aile ve Sosyal Politikalar İl Müdürlüğü' nün ve \%95,5'i ise Kızılay'ın yardımları hakkında bilgi sahibi değildir.

$\mathrm{Bu}$ bilgiler ışığında katılımcıların en fazla haberdar oldukları sosyal yardım kurumunun \%45 oranla Sosyal Yardımlaşma ve Dayanışma Vakfı olduğu görülmektedir. Ancak katılımcıların neredeyse tamamı diğer kurumlar tarafından verilen sosyal yardımlardan haberdar değildirler. Bu noktada "yoksul bireyler neden yardımlardan haberdar değil?" ve "yoksullar nasıl yardımlar hakkında bilgilendirilebilir?" sorularını cevaplandırmak önem teşkil etmektedir. Çünkü sosyal yardımlar ile bireylerin yoksulluklarının hafifletilmesi için taşra teşkilatı ve yerel yönetimler bir çaba göstermekte, ancak çaba yoksul kişilere ulaşamamaktadır.

Tablo 8: Kurum/Kuruluşların Sosyal Yardımlarından Haberdarlık Durumuna ait Bilgiler

\begin{tabular}{llcc}
\hline Kurumlara ait Yardımlar & & $\mathbf{N}$ & \% \\
\hline $\begin{array}{l}\text { Vakıflar genel müdürlüğünün } \\
\text { “Muhtaç Yardımı"ndan yararlanıyor } \\
\text { musunuz? }\end{array}$ & Evet & 9 & 4,5 \\
\cline { 2 - 4 } & Hayır & 191 & 95,5 \\
\cline { 2 - 4 } & Toplam & $\mathbf{2 0 0}$ & $\mathbf{1 0 0 , 0}$ \\
\hline
\end{tabular}




\begin{tabular}{|c|c|c|c|}
\hline \multirow{3}{*}{$\begin{array}{l}\text { Vakıflar genel müdürlüğünün aşevi } \\
\text { ve kuru gıda yardımı hizmetlerinden } \\
\text { yararlanıyor musunuz? }\end{array}$} & Evet & 12 & 6,0 \\
\hline & Hayır & 188 & 94,0 \\
\hline & Toplam & 200 & 100,0 \\
\hline \multirow{3}{*}{$\begin{array}{l}\text { Belediyenin gıda yardımlarından } \\
\text { yararlanıyor musunuz? }\end{array}$} & Evet & 40 & 20,0 \\
\hline & Hayır & 160 & 80,0 \\
\hline & Toplam & 200 & 100,0 \\
\hline \multirow{3}{*}{$\begin{array}{l}\text { Belediyenin giysi yardımlarından } \\
\text { yararlanıyor musunuz? }\end{array}$} & Evet & 9 & 4,5 \\
\hline & Hayır & 191 & 95,5 \\
\hline & Toplam & 200 & 100,0 \\
\hline \multirow{3}{*}{$\begin{array}{l}\text { Belediyenin çalışmayan vatandaşlara } \\
\text { kariyer merkezinde iş bulduğundan } \\
\text { haberdar mısınız? }\end{array}$} & Evet & 29 & 14,5 \\
\hline & Hayır & 171 & 85,5 \\
\hline & Toplam & 200 & 100,0 \\
\hline \multirow{3}{*}{$\begin{array}{l}\text { Sosyal yardım ve dayanışma } \\
\text { vakfından haberdar mısınız? }\end{array}$} & Evet & 75 & 37,5 \\
\hline & Hayır & 125 & 62,5 \\
\hline & Toplam & 200 & 100,0 \\
\hline \multirow{3}{*}{$\begin{array}{l}\text { Aile ve Sosyal Politikalar İl } \\
\text { Müdürlüğüünün yardımlarından } \\
\text { haberdar mısınız? }\end{array}$} & Evet & 46 & 23,0 \\
\hline & Hayır & 154 & 77,0 \\
\hline & Toplam & 200 & 100,0 \\
\hline \multirow{3}{*}{$\begin{array}{l}\text { Kızılay'ın yardımlarından haberdar } \\
\text { mısınız? }\end{array}$} & Evet & 9 & 4,5 \\
\hline & Hayır & 191 & 95,5 \\
\hline & Toplam & 200 & 100,0 \\
\hline
\end{tabular}

Sosyal yardımlardan yararlandığını belirten 133 katılımcının yaklaşık \%65'i sürekli yardım almaktadır. \%73,7'si (98 kadın) yardım başvurusunu bizzat kendisi yapmaktadır. Bu sonuç literatür ile benzerdir. Literatürdeki bulgulara göre kadınlar erkeklere kıyasla yardım istemekte daha az çekingen kalmaktadır. Bu durumun altındaki neden ise kadın ve erkeğe yüklenen toplumsal rollerin farklı olmasıdır. Kadınlar hane içindeki bireylerin özellikle çocuklarının gıda ya da giyim gibi temel 
ihtiyaçlarını karşılamada kendilerini daha fazla sorumlu hissetmekte ve bu sebeple yardım istemekten çekinmemektedir.

Katılımcıların ne tür yardım aldıklarına ilişkin bilgiler Tablo 9'da verilmektedir.

Tablo 9: Katılımcıların Yardım Aldıkları Alanlara ait Bilgileri

\begin{tabular}{lr}
\hline Yardım Türleri & $\%$ \\
\hline Nakit para & 27,5 \\
\hline Yakıt & 27,1 \\
\hline Gida & 22,1 \\
\hline Giyecek & 5,0 \\
\hline Eğitim & 3,1 \\
\hline Konut & 2,3 \\
\hline Diğer & 12,9 \\
\hline Toplam & $\mathbf{1 0 0 , 0}$ \\
\hline
\end{tabular}

Tablo 9'a göre katılımcıların en çok aldıkları yardım türleri nakit para, yakıt ve gıda yardımıdır. Katılımcıların bu yardımlar sonucu haneye sağladıkları parasal katkı ise \%55,3'ü için 301-600 € ve \%30,6'sı için 300 € ve altı aralığındadır.

Yoksul kadınların \%79,7'si yardım alırken herhangi bir zorlukla karşılaşmadığını belirtmiştir. Zorlukla karşılaşan katılımcılar, bürokratik işlerin ağır olması, kurumların menfi tavırları, okuma-yazma bilmediklerinden dolayı yardım alırken doldurulan evraklarda güçlük çekme gibi nedenlerden dolayı zorluk çektiklerini ifade etmişlerdir. Yoksul kadınların \%50,4'ü yardım aldığı kuruluşun imkânlarını yeterli bulurken \%49,6'sı yeterli bulmamaktadır.

Yardımlardan faydalanan kadınların \%80,5'i aldığı yardımları çevresindeki kişilere önerirken \%19,5'i önermemektedir. Katılımcıların \%84,2'si alınan yardımlarla sosyal aktivitelerinde bir değişikliğin olmadığını belirtirken \%15,8'i artış sağladığını dile getirmiştir.

Katılımcıların \%83,5'i yardımları geleceğe umutla bakmak için yeterli bulmazken \%16,5'i yeterli bulmaktadır. Katılımcıların \%94,9'u düzenli bir işi olsa yardım almayacaklarını söylerken \%5,1'i düzenli bir işi olsa dahi yardım alacağını söylemiştir.

Tablo 10 'da tüm katılımcıların sosyal yardımlar ile ilgili genel görüşlerine ait bilgiler verilmektedir. 
Tablo 10: Katılımcıların Sosyal Yardımlara ait Genel Görüşleri

\begin{tabular}{|c|c|c|c|}
\hline & & $\mathbf{N}$ & $\%$ \\
\hline \multirow{3}{*}{$\begin{array}{l}\text { Yardım alan herkesin ihtiyaç } \\
\text { sahibi olduğunu düşünüyor } \\
\text { musunuz? }\end{array}$} & Evet & 91 & 45,5 \\
\hline & Hayır & 109 & 54,5 \\
\hline & Toplam & 200 & 100,0 \\
\hline \multirow{3}{*}{$\begin{array}{l}\text { Yardımların adil bir şekilde } \\
\text { dağıtıldı̆̆ını } \\
\text { musunuz? }\end{array}$} & Evet & 48 & 24,0 \\
\hline & Hayır & 150 & 76,0 \\
\hline & Toplam & 200 & 100,0 \\
\hline \multirow{3}{*}{$\begin{array}{l}\text { Süresiz yardımlar insanları } \\
\text { tembelliğe alıştırıyor mu? }\end{array}$} & Evet & 163 & 81,5 \\
\hline & Hayır & 37 & 18,5 \\
\hline & Toplam & 200 & 100,0 \\
\hline \multirow{3}{*}{$\begin{array}{l}\text { Toplumun diğer kesimleri } \\
\text { yoksullara yardım etmeli mi? }\end{array}$} & Evet & 184 & 92,0 \\
\hline & Hayır & 16 & 8,0 \\
\hline & Toplam & 200 & 100,0 \\
\hline \multirow{3}{*}{$\begin{array}{l}\text { Eğitim durumu arttıkça } \\
\text { alınan yardımların } \\
\text { azalacağını düşünüyor } \\
\text { musunuz? }\end{array}$} & Evet & 154 & 77,0 \\
\hline & Hayır & 46 & 23,0 \\
\hline & Toplam & 200 & 100,0 \\
\hline
\end{tabular}

Tablo 10'a göre katılımcıların \%54,5'i (109 kişi) yardım alan herkesin ihtiyaç sahibi olmadığını düşünürken \%76,0'1 (150 kişi) yardımların adil dağıtıldığına inanmamaktadır. Katılımcıların \%81,5'i süresiz yardımların insanları tembelliğe alıştırdığına ve \%92,0'1 toplumun diğer kesimlerinin yoksullara yardım etmesi gerektiğine inanmaktadır. Ayrıca katılımcıların \%77,0'ı eğitim durumu arttıkça alınan yardımların azalacağını ifade etmiştir.

\section{Sonuç}

Günümüzde kadınların cinsiyet eşitsizliğine karşı verdikleri mücadelede seslerini daha fazla duyurabilmeleri, eşit eğitimden eşit ücrete kadar çeşitli haklar elde etmeleri ve daha fazla istihdam olanağı yakalamaları gibi olumlu gelişmeler 
yaşanmakta, ancak bu gelişmeler kadın yoksulluğunu ortadan kaldırmaya, hatta azaltmaya yetmemektedir. Böylece kadınlar karşı cinslerine göre yoksulluktan daha fazla etkilenmekte ve yoksulluğa karşı daha fazla mücadele etmektedir. Yoksullukla mücadelelerinde kadınlara birçok sosyal yardımlaşma kurumu da yardımcı olmaya çalışmaktadır. Ancak "Sosyal yardımlardan kadınlar haberdar mı?" ve "Verilen destekler kadınların sorunlarını çözüme kavuşturabilmekte mi?" sorularını cevaplandırmak önem teşkil etmektedir. Bu doğrultuda çalışmada farklı kurumlar tarafından verilen sosyal yardımların yoksulluk ile mücadeledeki rolünü ve kadınların bu kurumlara bakış açısını tespit etmek amaçlanmıştır

Çalışmada Erzurum il merkezine bağlı üç ilçe belediyesinde (Yakutiye, Palandöken, Aziziye) ikamet eden ve görece olarak daha düşük gelir grubunda (ilk \%10'luk dilimde) yer alan 200 kadın ile bir anket araştırması yürütülmüştür.

Araştırma sonuçlarına göre kadınlar; aileleri, çevreleri ya da özel vakıf/şahısların yardımlarından ziyade, farklı resmi kurumlar tarafından verilen sosyal yardımlara daha fazla yönelmektedir. Özellikle hane geliri azaldıkça kadınların sosyal yardımlara ihtiyacı daha fazla artmakta ve daha fazla kadın yardımlardan yararlanmak için başvuru yapmaktadır. Örneğin; 1500 € ve altı gelire sahip kadınların \%66'sı sosyal yardım alırken bir üst gelir grubunda (1501-3000 £) yardım alanların oranı \%33'e düşmektedir. Bu sonuç hane geliri düştükçe en temel ihtiyaçların bile karşılayamayan insanlar için sosyal yardımların ne kadar önemli olduğunun bir göstergesidir. Yardımlar sayesinde kadınlar az miktarda da olsa hanelerine ek bir gelir sağlamaktadır. Araştırma bulgularına göre yardımlardan faydalanan katılımcıların bu yolla ailelerine sağladıkları gelir ortalama 300-600 £ aralığındadır. Söz konusu miktar sorunları çözmemekte, ancak gıda, yakıt gibi en temel ihtiyaçlarında kadınlara katkı sağlamaktadır. Bununla birlikte kadınların farklı kurumlar tarafından düzenlenen sosyal yardımlara ilişkin bilgi düzeyi oldukça düşüktür.

Sonuçlara göre katılımcıların \%45'i Sosyal Yardımlaşma ve Dayanışma Vakfı'nın düzenlediği yardımlardan haberdardır. SYDV Türkiye'nin il-ilçe boyutunda tamamına yayılmış en temel sosyal yardım kuruluşudur. Kurum daha fazla yoksul insana ulaşırken yoksullar da söz konusu kuruma daha kolay ulaşabilmektedir. Ancak diğer kurumlar tarafından verilen yardımlardan katılımcıların neredeyse tamamı haberdar değildir. Bu sonuç, sosyal yardımlar ile bireylerin yoksulluğunu hafifletmeye çalışan diğer taşra teşkilatı ve yerel yönetimlerin çabalarının yoksul kişilere ulaşamadığını göstermektedir. Bu nedenle farklı kurumların kendi tüzel kişilikleri ile yardım dağıtmak çabası yerine, SYDV'ye destek olmaları ve tek bir çatı altında yardımları düzenlemeleri daha fazla kişiye ulaşma olanağ 1 yaratacaktır. Ancak bu noktada diğer önemli bir problem de Türkiye' de yardımların başvuru esasına göre ve düzensiz bir biçimde verilmesidir. 
Başvuru esası, çeşitli kanallarla yardımlara ilişkin bilgiye ulaşan kişileri kapsamaktadır (Şener, 2010). Araştırma sonuçlarına göre kadınlar genellikle eş-dost aracılığıyla yardımlardan haberdar olmaktadır. Ancak bu bilgi paylaşımı yeterli gelmemektedir. Başvuru esasına göre verilen sosyal yardımların adil dağıtımını gerçekleştirebilmek mümkün değildir. Bu nedenle yoksul kişileri ve haneleri tespit edip onlara düzenli yardım ulaştıracak bir ağ yapısının oluşturulması gerekmektedir. Böylece hem yardımların sürekliliği sağlanabilecek hem de kadınlarda oluşan "yardımlar gerçek ihtiyaç sahiplerine dağıtılmıyor" yargısı kırılabilecektir.

Araştırmadan elde edilen bir başka önemli bulgu da kendini yoksul hisseden, ancak herhangi bir sosyal yardım almayan kadınlar ile ilgilidir. Araştırmada kendini yoksul hisseden, ancak yardım almayan katılımcıların oranı yaklaşık \%53'dür. Bu katılımcıların neredeyse tamamının eşi düzenli bir işe (memur, işçi, esnaf, emekli vb.) ve gelire sahiptir. Bu yüzden söz konusu katılımcılar sosyal yardımlardan yararlanamamaktadır. Çünkü Türkiye'de sosyal yardımların büyük bir çoğunluğu, işgücü piyasası dışında kalan düşük gelirli bireylere yöneliktir. Böyle bir uygulamada çalışan kişilerin yeterli gelir elde ettikleri varsayılmaktadır. Ancak bulgulara göre söz konusu katılımcılar 1500-4000 € arasında değişen gelire sahiptir ve bu gelir düzeyi Türkiye' deki dört kişilik bir hane için yoksulluk sınırının oldukça altındadır. Üstelik düzenli bir işe sahipse kişi ailesinden ya da çevresinden yardım istememekte ya da isteyememektedir. Çünkü sadece devlet değil, toplumda çalışan kişiyi ve onun ailesini yoksul olarak görmemektedir. Bu nedenle yoksulluğun ve yoksulun nesnel bir tanımlamasının yapılması önem teşkil etmektedir. Böylece doğrudan kaynak transferi olan sosyal yardımlar doğru kişilere ulaştırılabilecektir

Sonuç olarak kısa vadede bir çözüm yolu olan sosyal yardımlar gıda, yakacak, eğitim, sağlık gibi temel ihtiyaçlarını karşılayamayan bireylere önemli ölçüde katkı sağlamaktadır. Ancak günümüzde yoksullukla mücadelede bu tarz maddi yardımlar giderek önemini kaybetmeye başlamıştır. Günü kurtarmayı amaçlayan yardımların yerine daha kalıcı çözüm yollarının aranması gerekmektedir. Örneğin; kişilerin mesleki yeterliliklerinin geliştirilmesi ve istihdam olanaklarının yaratılması ya da kişilere kendi iş imkânlarını oluşturacak sermayenin sağlanması vb. uygulamalara ihtiyaç duyulmaktadır. Özellikle emek arzı ve talebi arasında uyum sağlayan ve talebin istekleri doğrultusunda emeği hazırlayan aktif bir işgücü politikasının oluşturulması önem teşkil etmektedir.

\section{Kaynakça}

Aca, Z. (2018). Türkiye'de Kamusal Sosyal Yardımların Yapabilirlik Yaklaşımı Çerçevesinde Etkinliği Analizi: Bursa Örneği. Uludağ Üniversitesi Sosyal Bilimler Enstitüsü, Doktora Tezi, Bursa. 
Adaman, F. \& Keyder, Ç. (2006). Türkiye'de Büyük Kentlerin Gecekondu ve Çöküntü Mahallelerinde Yaşanan Yoksulluk ve Sosyal Dışlanma. http://ec.europa.eu/employment_social/social_inclusion/docs/2006/study_turk ey_tr.pdf.

Akçiçek, A. (2016). Dünyada Yoksullukla Mücadele Yaklaşımları ve Temel Politiklar. http://www.hurfikirler.com/dunyada-yoksullukla-mucadeleyaklasimlari-ve-temel-politikalar (Erişim Tarihi: 15.04.2019).

Alptekin D., \& Aksan G. (2010). Yoksulluk ve Kadın: Teorik ve Uygulamalı Bir Çalışma. Uluslararası Yoksullukla Mücadele Stratejileri Sempozyumu: Deneyimler ve Yeni Fikirler Bildiriler Kitabı (ss. 413-426). T.C. Başbakanlık Sosyal Yardımlaşma ve Dayanışma Genel Müdürlüğü.

Apaydin, A. (2011). Social Assistance as a Poverty Alleviation Strategy: Case of Altındağ Social Assistance and Solidarity Foundation. ODTÜ Sosyal Bilimler Enstitüsü, . Yayınlanmamış Yüksek Lisans Tezi, Ankara.

Arpacıoğlu, Ö. \& Yıldırım, M. (2011). Dünyada ve Türkiye'de Yoksulluğun Analizi. Niğde Üniversitesi İ̈BF Dergisi, 4 (2), 60-76.

Batur, E.B. (2011). Nevşehir'de Kadın Yoksulluğu. Nevşehir Üniversitesi Sosyal Bilimler Enstitüsü, Yayımlanmamış Yüksek Lisans Tezi, Nevşehir.

Berber E., S. (2016). Muşun Güneyik Köyü'nde Kadın Yoksulluğu ve Suya Erişim. Hacettepe Üniversitesi Sosyal Bilimler Enstitüsü, Doktora Tezi, Ankara.

Buğra, A. (2011). Kapitalizm, Yoksulluk ve Türkiye'de Sosyal Politika. İstanbul: İletişim Yayınları.

Buğra, A., \& Keyder, Ç. (2002). Bir Temel Hak Olarak Vatandaşlık Gelirine Doğru. İstanbul: İletişim Yayınları.

Burkett, P. (1990). Poverty Crisis In The Third World -The Contradicitions of World Bank Policy. Monthly Review Archives, 42 (7), 20-32.

Çakar Yakut, B. \& Yılmaz, V. (2010). Gelir Hakkı Neden Sol Bir Talep?. Türk-iş Dergisi, 386, 1-13.

Emir, İ. (2009). Van İli Erdemit Merkez Sağlık Ocağı Bölgesinde Kadınların Toplumsal Cinsiyeti Nasıl Yaşadığı ve Bu Durumun Kadın Yoksulluğuna Etkisinin Değerlendirilmesi. Yüzüncüyıl Üniversitesi Sosyal Bilimler Enstitüsü, Yüksek Lisans Tezi, Van.

Ersoy, A. (2012). İktisadi Düşünceler Tarihi (1. Basım). Ankara: Nobel Akademik Yayıncilik.

Eymen. U. E. (2007). SPSS 15.0 Veri Analiz Yöntemleri. İstatistik Merkezi Yayın.

Gough, I. (2010). Güney Avrupa'da Sosyal Yardım. Sosyal Politika Yazıları içinde (231-260). İstanbul: İletişim Yayınları. 
Gülşen S. (2019). Veri Zarflama Analizi Tekniği ile Sosyal Yardımlaşma ve Dayanışma Vakfının Gerçekleştirdiği Sosyal Yardımların Etkinlik Ölçümü: Arıcak Sosyal Yardımlaşma Ve Dayanışma Vakfı Örneği. Fırat Üniversitesi Sosyal Bilimler Enstitüsü, Yayınlanmamış Yüksek Lisans Tezi, Elazı̆̆.

Güneş, F. (2014). Yoksullukla Başa Çıkma Stratejileri, Kaynakların Yoksulluğu mu? Kadın Emeği Merkezli Eleştirisel Bir Analiz. Yoksulluk ve Kadın, 29-128.

Güneş, M. (2012). Yoksullukla Mücadelede Sosyal Yardımların Bir Kamu Yönetimi Politikası Olarak Sürdürülebilirliği. SÜ İ̈BF Sosyal ve Ekonomik Araştırmalar Dergisi, 12 (24), 149-184.

İlter, O. (2009). Sosyal Yardım Alanında SYDV ve STK İş birliği, Sorunlar, Çözüm Önerileri. T.C. Başbakanlık Sosyal Yardımlaşma ve Dayanışma Genel Müdürlüğü, Sosyal Yardım Uzmanlık Tezi, Ankara.

Karagül, M. (2012). Dünya Ekonomisi. Ankara: Nobel.

Kaya, E. (2009). Yoksullukla Mücadelede Avrupa'nın ve Türkiye'nin Sosyal Yardım Modeli. SYDGM, Uzmanlık Tezi, Ankara.

Kızılay. Neler Yapıyoruz. www.kizilay.org.tr/neler-yapiyoruz (Erişim Tarihi: 23.04.2019).

Kızılay. www.kizilay.org.tr/Kurumsal (Erişim Tarihi: 24.04.2019).

Koray, M. (2000). Sosyal Politika. Bursa: Ezgi Kitabevi.

Kula, D. N. \& Kula, S. (2007). Kadın Sorununa Yönelen Sivil Toplum Örgütlerinin Kadınların Yoksulluğu Konusuna Eğilimleri. A. Akdemir vd. (Ed.). IV. Uluslararası Sivil Toplum Kuruluşları Kongresi Bildiriler Kitabı Küresel Yoksulluk (ss. 461-479). Ankara: Pozitif Yayıncilik.

Metin, O. (2011). Sosyal Politika Açısından AKP Dönemi: Sosyal Yardım Alanında Yaşananlar. Çalışma ve Toplum Dergisi, 1 (28), 179-200.

Özen, Y. \& Gül, A. (2007). Sosyal ve Eğitim Bilimleri Araştırmalarında EvrenÖrneklem Sorunu. Atatürk Üniversitesi Kazım Karabekir Eğitim Fakültesi Dergisi, 0 (15), 394-422.

Özgüler, V. C. (2014). Gelir, Servet ve Yoksulluk (1.Baskı). İstanbul: Cinius.

Öztürk, Ş. (2008). Kırsal Yoksulluk. A. Duru Salıcı (Ed.). Türkiye'de Yoksulluk Çalışmaları (ss. 265-299). İzmir: Yakın Kitabevi.

Sample Size Calculator. (2019). http:/ / www.surveysystem.com/sscalc.htm

SYDGM (2006). 2006 Yilı Faaliyet Raporu.

Şener, Ü. (2010). Yoksullukla Mücadelede Sosyal Güvenlik, Sosyal Yardım Mekanizmaları ve İş Gücü Politikaları. Türkiye Ekonomi Politikaları Araştırma Vakf1 Politika Notu, 2-22. 
Şenses, F. (2014). Küreselleşmenin Öteki Yüzü Yoksulluk. İstanbul: İletişim Yayınları.

T.C. Aile ve Sosyal Politikalar Bakanlığı. Eğitim Yardımları. https:// sosyalyardimlar. aile.gov.tr/ egitim-yardimlari (Erişim Tarihi: 20.04.2019).

T.C. Aile ve Sosyal Politikalar Bakanlığı. Proje Destekleri. https:// sosyalyardimlar. aile.gov.tr/proje-destekleri (Erişim Tarihi: 21.04.2019).

T.C. Aile ve Sosyal Politikalar Bakanlığı. Sosyal Yardım Programlarımız. https:// sosyalyardimlar.aile.gov.tr/sosyal-yardim-programlarimiz (Erişim Tarihi: 20.04.2019).

T.C Çalışma ve Sosyal Güvenlik Bakanlığı (2018). 2017 Yılı Maliyet Raporu.

T.C. Milli Eğitim Bakanlığı (2017). Milli Eğitim İstatistikleri. T.C. Milli eğitim Bakanlığı Strateji Geliştirme Başkanlığı, Ankara.

T.C. Resmi Gazete (2005). Belediye Kanunu. https:// www.mevzuat.gov.tr/ Mevzuat Metin/1.5.5393.pdf (Erişim Tarihi: 17.04.2019).

T.C. Sağlık Bakanlığı (2015). Görev ve Yetkileri. www.saglik.gov.tr/TR,11464/gorev-ve-yetkiler.html (Erişim Tarihi: 16.04.2019).

T.C. Vakıflar Genel Müdürlü (2018). 2017 Faliyet Raporu.

Türkiye İstatistik Kurumu (2017). İstatistiklerle Kadın. www.tuik.gov.tr (Erişim Tarihi: 26.08.2018).

Türkiye İstatistik Kurumu (2018). Gelir ve Yaşam Koşulları Araştırması. www.tuik.gov.tr (Erişim Tarihi: 11.04.2018).

TÜRK-IŞ, (2019). Eylül 2019 Açlık ve yoksulluk Sınırı. http://www.turkis.org.tr/EYLUL-2019-ACLIK-ve-YOKSULLUK-SINIRI-d290748.

Uçar, C. (2011). Kadın Yoksulluğu ile Mücadelede Sosyal Politika Araçları ve Etkinlikleri. Ankara: Afşaroğlu Matbaası.

Uzunsakal, E. \& Yıldız, D. (2018). Alan Araştırmalarında Güvenilirlik Testlerinin Karşılaştırılması ve Tarımsal Veriler Üzerine Bir Uygulama. Uygulamalı Sosyal Bilimler Dergisi, 2 (1), 14-28.

Yaşar, R. \& Açıkgöz, R. (2011). Yoksullukla Mücadelede Bütüncül Bir Politika: İnsani Gelişme ve Yardım Merkezi. Elektronik Sosyal Bilimler Dergisi, 10 (6), 405429.

Yusufoğlu, Ö. (2010). Kadın Yoksulluğu Üzerine Sosyolojik Bir Araştırma Elazı̆̆ Örneği. Frrat Üniversitesi Sosyal Bilimler Enstitüsü, Yüksek Lisans Tezi, Elazığ. 